\title{
Benefits of simulation training in medical education
}

This article was published in the following Dove Press journal:

Advances in Medical Education and Practice

18 July 2016

Number of times this article has been viewed

Tamkin Abas

Fatema Zehra Juma

Manchester Medical School, University of Manchester, Manchester, UK

Correspondence: Tamkin Abas

2 Dennis Avenue, Wembley, Middlesex

HA9 8AZ, UK

Tel +44754284245I

Email tamkin.abas@student.manchester. ac.uk

\section{Dear editor}

We read about the satisfaction of simulation experiences of paramedic students ${ }^{1}$ with great interest. As medical students, with early clinical experience comparative to paramedic training in the UK, we agree that simulation-based learning is well received in health care education. As part of the curriculum at the University of Manchester, we are exposed to a variety of simulation-based environments, ranging from examining simulated patients to practicing resuscitation and emergency care on mannequins. We would like to provide insight into our understanding of where simulation training fits into health care education and highlight a key aspect of its satisfaction that we feel has been overlooked.

What differentiates health care education from other courses in higher education is that it provides a vocational qualification, producing professionals who not only have substantial knowledge in their field, but are trained on how to apply this to provide a service. Health care education can be broadly split into two domains - the theory or knowledge, and the ability to apply this in a practical environment to help patients and work as a team. This practical application of knowledge is where simulation-based learning fits into health care education.

Williams et $\mathrm{al}^{1}$ demonstrated that the simulation experience was rated as a valuable learning experience $(P<0.001)$ and highlight that this is linked with better academic performance. The study revealed that satisfaction was partly due to the simulation providing a method of consolidating learning and developing clinical reasoning. Our experiences have shown that it also works to deepen understanding by enabling linking of different aspects of the theory. Simulation training provides an opportunity to apply theory and gain experience in skills or procedures that would otherwise be difficult without potentially putting patients at risk, such as managing emergency situations and resuscitation. ${ }^{2}$ We believe this is the only way to gain such experience which is essential for any health care professional.

A key aspect of satisfaction with simulation training that we believe is not highlighted in this study is that it provides students with the confidence to manage similar real-life scenarios. We believe that, in many situations, confidence is directly linked to competence, for example, the robust communication skills needed when interacting with patients requires being able to handle the situation with confidence. The practice provided by simulation training builds up confidence and hence satisfaction, 
as students would feel more competent to handle real-life situations in the future. ${ }^{3}$

Many students in this study felt that the simulation training developed their clinical decision-making abilities. We believe one of the reasons for this is that, as students gain confidence, they are more comfortable in making their own decisions and exerting their autonomy. As well as confidence being essential for an individual, demonstrating confidence is important for the patients who have put a lot of trust in health care professionals. ${ }^{4}$

It is important to recognize that although for the majority of students practice will improve confidence, given the variety of learning styles, simulation training may not boost confidence for all students to the same degree.

From a medical student's outlook, this paper explores a significant matter that we feel reflects our perspective of health care education. Not only is simulation training crucial for the professional half of health care training but, for us, it forms an integral part of our yearly assessments. Williams et al highlight several reasons for student satisfaction with regard to simulation training and we believe confidence to be a key part of this. We feel it would be important to include metrics on confidence when assessing satisfaction in simulation training in the future.

\section{Disclosure}

The authors report no conflicts of interest in this communication.

\section{References}

1. Williams B, Abel C, Khasawneh E, Ross L, Levett-Jones T. Simulation experiences of paramedic students: a cross-cultural examination. $A d v$ Med Educ Pract. 2016; 7:181-186.

2. Beckers SK, Timmermann A, Müller MP, Angstwurm M, Walcher F. Undergraduate medical education in emergency medical care: a nationwide survey at German medical schools. BMC Emerg Med. 2009;9:7.

3. Hecimovich M, Volet S. Development of professional confidence in health education: research evidence of the impact of guided practice into the profession. Health Educ. 2011;111(3):177-197.

4. Wang Z, Liu Q, Wang H. Medical simulation-based education improves medicos' clinical skills. J Biomed Res. 2013;27(2):81-84.

\begin{abstract}
Dove Medical Press encourages responsible, free and frank academic debate. The content of the Advances in Medical Education and Practice 'letters to the editor' section does not necessarily represent the views of Dove Medical Press, its officers, agents, employees, related entities or the Advances in Medical Education and Practice editors. While all reasonable steps have been taken to confirm the content of each letter, Dove Medical Press accepts no liability in respect of the content of any letter, nor is it responsible for the content and accuracy of any letter to the editor.
\end{abstract}

Advances in Medical Education and Practice

Dovepress

\section{Publish your work in this journal}

Advances in Medical Education and Practice is an international, peerreviewed, open access journal that aims to present and publish research on Medical Education covering medical, dental, nursing and allied health care professional education. The journal covers undergraduate education, postgraduate training and continuing medical education including emerging trends and innovative models linking education, research, and health care services. The manuscript management system is completely online and includes a very quick and fair peer-review system. Visit http://www.dovepress.com/testimonials.php to read real quotes from published authors. 